\title{
NOTES ON THE INSHORE PLANKTON OF PLYMOUTH
}

By Marie V. Lebour, D.Sc.

From the Plymouth Laboratory

(Text-fig. I)

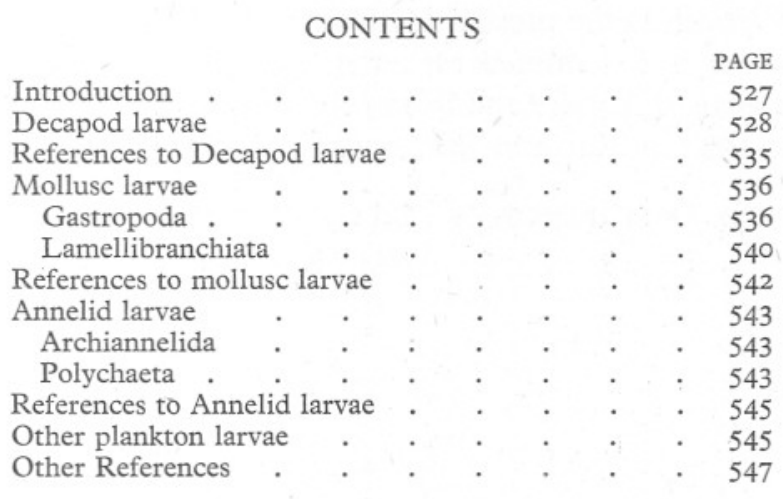

INTRODUCTION

During the years 1940-5 plankton samples were examined regularly from inside the Plymouth Breakwater, with the exception of a few months. Although it was not possible to do any quantitative work, special attention was given to larval forms, especially of the decapods, molluscs and annelids. The presence of these larvae gave a good idea of the breeding seasons of the various species. As it is only recently that many of these larvae have been identified, this is the first time that detailed specific notes have been made of their presence; and it is thought to be worth while to publish these results. To help those who wish to identify the larvae, a reference to a description of each species is given whenever possible, in square brackets after its name. It should be clearly understood that the absence of any species from these notes does not necessarily imply that it might not have been there, although all the samples were carefully examined. Most of the Coelenterates, the Cirripedia, Copepoda, and young fishes, are omitted here. Of the remaining ingredients of the plankton, various records were kept; and the occurrence of the more noteworthy of these forms, according to months, is shown in Table I.

Very rarely there was an indication of an inflow of Atlantic water, or of windborne Atlantic organisms, for instance, Doliolum in August and September 1942, and a very young Velella float in February 1943, on which separate comment is made (Lebour, 1947). Sagitta setosa was, as is to be expected, the 
prevailing species of this genus, but $S$. elegans occurred in I94I on I January and 3 February; in I943 on I3, I7 and I8 May; in I945 on 2I February, I3 (in numbers) and I7 April. On 2I August 1940, Mr O. D. Hunt reported that Salpa fusiformis Cuv. was abundant in tow-nettings from the mouth of the River Yealm. At this time Muggiaea atlantica Cunningham was specially abundant in the Plymouth inshore waters and a few specimens of Stephanomia bijuga (Della Chiaje) were also seen.

Muggiaea atlantica Cunningham [Cunningham, I892], regarded by Russell as an inhabitant of south-western waters, occurred in any month except February and March in the present samples: in 1940 from August to October (the plankton was not examined earlier in the year); in I94I from June to December; in 1942 in January and from July to December; in 1943 from April to October; in 1944 in May and June only; in 1945 from June to November.

Table I. Occurrences of Certain Planktonic Organisms

Noctiluca Month ... J. F. M. A. M. J. J. A. S. O. N. D.

Muggiaea atlantica

Stephanomia bijuga

Oikopleura dioica

Fritillaria sp.

Doliolum

Sagitta setosa

S. elegans

It is usually abundant in summer and autumn, rare or absent in winter and spring. Its occurrence in January in 1942 probably indicated the remnant of the autumn growth. In April and May 1943, and in May 1944, when it only began to be abundant at the end of that period, it may have been unusually early, or possibly very late. Russell (1934) states that this species and also $M$. kochi (Will) occurring in our waters generally first appear towards the end of the summer and often continue on through the autumn to the January or February in the following year. Russell (1934) has shown that M. atlantica and $M$. kochi occur in alternating periods, and one species does not overlap the other. M. atlantica occurred in an unbroken series from I9I3 to 1924 (excepting 1915 when none was seen); in 1925 M. koch $i$ appeared and M. atlantica was no longer there. M. kochi stayed until 1936 (excluding 1932), and during the whole of that period no M. atlantica were seen. After January 1936 M. atlantica was again abundant (Russell, 1938) and M. kochi absent. Probably $M$. atlantica has occurred from 1936 onwards to the present time-a period of ten years.

\section{DeCAPod LaRvae}

Table II marks the larvae present throughout the year in months. The only species present in every month are Carcinus maenas, Portunus depurator, Macropodia sp. and Hippolyte varians. Crangon vulgaris, Porcellana longicornis, Galathea strigosa, Portunus puber, Pagurid larvae indet., and Spirontocaris sp. 
are present in every month except December. The other larvae appear in various months, some of them very definite in their seasons. The majority abound in

\section{TABLE II}

Larvae present

Carcinus maenas

Month ... J. F. M. A. M. J. J. A. S. O. N. D.

Portunus depurator

P. puber

P. pusillus

P. holsatus

P. marmoreus

Cancer pagurus

Atelecyclus septemdentatus

Pilumnus hirtellus

Portumnus latipes

Xantho spp.

Thia polita

Corystes cassivelaunus

Gonoplax rhomboides

Pinnotheres veterum

Ebalia spp.

Eurynome aspera

Maia squinado

Inachus spp.

Macropodia spp.

Hyas coarctatus

Porcellana longicornis

$P$. platycheles

Pagurid larva indet.

Galathea strigosa

$G$. squamifera

Munida banffica

Homarus vulgaris

Palinurus vulgaris

Faxea nocturna

Callianassa subterranea

Upogebia spp.

Alpheus ruber

Axius stirhynchus

Athanas nitescens

Crangon vulgaris

C. allmanni

Philocheras fasciatus

P. trispinosus

$P$. bispinosus

Leander serratus

L. squilla

Hippolyte varians

Spirontocaris sp.

Caridion steveni

Pandalus montagui

Pandalina brevirostris

Processa edulis

$P$. canaliculata

Nyctiphanes couchii nauplius

Do. calyptopis and furcilia larvae

$\times \times \times \times \times \times \times \times$

$\times \times \times \times \times \times \times \times \times$

$\times \quad \times \quad \times \quad \times \quad \times \quad \times \quad \times \quad \times \quad \times \quad \times \quad \times \quad$.

$\times \times \times \times \times$

. $\quad \dot{x} \quad \cdot \quad \times \quad \times$

. $\times \times \times \times$

. $\times \times \times \times \times$

$\begin{array}{lll}x & x \\ \times & x & x \\ x & x\end{array}$

$\times \quad \times$

$\times$

$\times$

$\times$
$\times \quad \times$

$x$

$\dot{x} \times$

$x$

$\times$

$\dot{x}$

$x$

the spring and summer, but nearly all the Thalassinids and the Alpheids are present from June to October only, Corystes from January to May, Portumnus latipes, Pinnotheres veterum and Gonoplax from June to September, and Thia in 
August and September. These are much the same in all years, showing definite breeding seasons. Portunus depurator zoea is much the commonest of the portunids inshore, $P$. puber coming next, but the others were not so easily recognizable and many may have been missed. The same applies to Xantho. The species of Ebalia were not differentiated, butare probably all E. tuberosa. Inachus and Macropodia were also recorded as sp.indet., Inachus is probably dorsettensis and Macropodia probably $M$. rostratus. The larva of the common lobster, Homarus vulgaris, is seldom seen, and then usually singly. The Phyllosoma of Palinurus, being a more outside form, occurs only occasionally, and several other outside species recorded here are not usual inhabitants of the inshore waters. Such species are Thia polita, faxea nocturna, Crangon allmanni, Philocheras trispinosus. Nyctiphanes couchii, placed here with the decapods, must occasionally breed not far from shore for nauplii were found once, and calyptopis and early furcilia stages several times.

The number of species recorded below which may be present in each month is: January I6, February 19, March 23, April 24, May 34, June 42, July 40, August 39, September 37, October 30, November 16, December 4. Thus December has the fewest, January and November coming next, and June has the largest number. First larvae are much more numerous than late stages.

Carcinus maenas (Pennant) [Lebour, 1928] is already known to breed throughout the year. The present records show larvae in the plankton in every month, with large numbers in June I94I, May, July 1942, May, July, Sept. I943, Jan., Feb., Mar., May 1944, Jan., Feb., Mar., June 1945. Fewest numbers occur in October, November and the beginning of December, when the numbers begin to rise.

Portunus depurator (L.) [Lebour, I928] is already known to breed in any month. The present records show larvae in every month, but they are much more numerous outside the Sound. There are few in January and February in the inshore waters, but they may be numerous from March to September, dwindling markedly in October to December. Large numbers occurred in July I94I, May 1942, March to August 1943, May and July 1944. They are never so abundant inshore as the zoeae of Carcinus.

Portunus pusillus Leach [Lebour, 1928]. The records of this species are probably not at all complete for the small Portunid zoeae are so much alike that it is difficult to be sure of their identity, and unidentified small Portunids have not been recorded. It is one of the earliest crabs in berry and continues at least to August. Zoeae were noted in the inshore plankton in January and February 1942, March to May 1943, February to July 1944, with large numbers in April, and only once in July 1945.

Portunus puber (L.) [Lebour, 1928] is already known to breed chiefly in spring and summer. The present records show larvae in the plankton from January to November, but those in autumn and winter are very rare. The 
largest numbers of zoeae occur in March to July, specially plentiful in July I94I and 1942, March and May I943, and May I944.

Portunus holsatus Fab. [Williamson, I9II; Lebour, I928]. Larvae have already been recorded in spring and summer. The present records are few and the zoeae were only seen in May and June, and then only in very small numbers.

Portunus marmoreus Leach [Lebour, 1928]. The larvae have already been recorded in spring and summer. The present records are few and the zoeae were only seen in March to June, and in October, and usually in very small numbers.

Portumnus latipes (Pennant) [Lebour, I944a]. The larvae are found occasionally in the plankton from inshore from June to September.

Cancer pagurus L. [Lebour, I928] breeds in spring and summer. The present records show the larvae in the inshore plankton from April to November, the largest numbers in May and July. None was seen in October, but they occur rarely as late as November.

Atelecyclus septemdentatus Leach [Lebour, 1928] is usually in the plankton from April to August. The present records show that it may be present as early as February and as late as November, but it usually occurs from March to September, the largest numbers in May to July.

Corystes cassivelaunus (Pennant) [Gurney, 1903; Lebour, 1928] is one of the earliest zoeae in the plankton, previous records showing it occurs from March to June, rarely later. The present records are from January to May. The largest number seen were in March 194I, but they are never very numerous so close inshore. Very large numbers sometimes occur in the outside waters.

Xantho spp. [Lebour, I928]. The species of Xantho were not distinguished from one another. They are rarely seen in the plankton, occurring in summer only.

Pilumnus hirtellus (L.) [Lebour, I928]. Zoeae in the inshore plankton were seen from May to November, never very abundant. Largest numbers occurred in July.

Thia polita Leach [Lebour, 1928] is rare and only the adult is found in outside waters. Zoeae were seen in the inshore plankton only in August and September I94I.

Gonoplax rhomboides (L.) [Lebour, I928]. Zoeae were seen in the inshore plankton from June to September, never very numerous. The largest numbers occurred in July.

Pinnotheres veterum Bosc [Lebour, I928]. Zoeae were seen in the inshore plankton from June to September, but always singly.

Ebalia spp. [Lebour, 1928]. The species of Ebalia zoeae were not distinguished, but most of them are almost certainly Ebalia tuberosa (Pennant) [Lebour, 1928]. Zoeae occurred in the inshore plankton from February to November, but never in large numbers, and chiefly from July to September. 
Maia squinado Herbst [Lebour, I927; I928]. Zoeae were rarely seen in the inshore plankton, occurring in the present records from April to October.

Eurynome aspera Leach [Lebour, 1928]. Zoeae were rarely seen in the inshore plankton from July to October. They are much more frequent outside the Sound.

Hyas coarctatus (Leach) [Lebour, 1928]. Zoeae are usually seen in early spring. In the present records they were only noted once, in March.

Inachus spp., probably dorsettensis (Pennant) [Lebour, I927; 1928]. The species of Inachus zoeae were not specially identified. They occur in the present records from May to October, but never in large numbers. Outside they are far more numerous.

Macropodia spp., probably chiefly rostratus (L.) [Lebour, I928]. Macropodia zoeae, the species not identified, were found in the inshore waters in every month of the year, but never in numbers.

Porcellana longicornis (L.) [Lebour, 1943]. Larvae occur in the inshore plankton in every month except December. They are commonest in the summer months, with a fair number in spring and very few in autumn and winter.

Porcellana platycheles (Pennant) [Lebour, 1943]. The larvae have a more restricted season than those of $P$. longicornis, occurring from April to September, and are most numerous in June.

Galathea squamifera Leach [Lebour, I93 I $a$ ]. These are some of the earliest larvae and occur in the inshore plankton from January to October. They are most numerous in April and May, but may be fairly plentiful up to July. Very few are recorded for August, rather more in September, and they were only seen once in January and October. May is usually the maximum month for breeding.

Galathea strigosa (L.) [Lebour, I930a]. The larvae, like those of G. squamifera, may be in the inshore plankton from January to October; also, very rarely, in November. Again they are most numerous in April and May, but they are not so common as $G$. squamifera, and probably occur much more often in the outside waters.

Munida banffica (Pennant) [Lebour, I930a]. This is an outside species, the adult not recorded from the Sound. Larvae were seen in the inshore plankton once in March, May and September.

Pagurid larvae. These were not identified, but probably were Eupagurus bernhardus (L.) [Sars, I889], E. prideauxi (Leach), and, possibly, Anapagurus laevis (Thompson). They occur, but not in large numbers, in the inshore plankton from January to November.

Homarus vulgaris Milne-Edwards [Sars, I875; Lebour, I944a]. Larvae usually occur singly and not frequently. The present records show them in the inshore plankton from June to September. 
Palinurus vulgaris Latreille [Bouvier, I914a; Lebour, I945]. The Phyllosoma larvae occur commonly in the outside plankton from February to September. The present records show them rarely in the inshore plankton from June to August.

Axius stirhynchus Leach [Webb, I92I]. Larvae occur in the inshore plankton from May to October, the largest numbers in July.

faxea nocturna (Chiereghin) [Bouvier, I9I4b]. The larvae are rarely found in the inshore plankton, usually outside the Sound, in summer. They only occurred once in the present records, in July.

Callianassa subterranea (Montagu) [Webb, I92I]. Previous records show larvae in the plankton to be very common in summer and early autumn. The present records show them in the inshore waters from June to October, chiefly in July.

Upogebia spp., including U. (Gebiopsis) deltaura Leach and U. stellata (Montagu) [Webb, I9I9]. The two species have not been separated. Previous records show larvae in the plankton to be very common in spring and summer. Webb (I919) found that U. stellata breeds rather earlier than $U$. deltaura. The present records show the larvae in the inshore plankton from April to November, commonest in July to September.

Athanas nitescens (Montagu) [Sars, I906; Webb, I921; Lebour, 1932]. Previous records show the larvae to be common in the plankton in summer and autumn, especially summer. The present records show them occurring from June to October, commonest in July, August and September.

Alpheus ruber Milne-Edwards [Lebour, 1932]. Previous records, which are for summer and early autumn, probably include the larvae of $A$. macrocheles (Hailstone). The present records of $A$. ruber in the inshore plankton are from June to October, fairly frequently, but never in large numbers.

Crangon vulgaris $\mathrm{L}$. [Sars, I890; Lebour, 193I $b$ ]. Larvae were previously known to occur practically throughout the year. The present records show that they are present from January to November, especially spring and summer. They may be numerous in any month from April to August, dwindling towards the autumn.

Crangon allmanni (Kinahan) [Sars, I890; Lebour, I93I $b$ ]. This is an outside species. Its larva is always early, and was found in the inshore plankton on only two occasions, in February and April.

Philocheras fasciatus (Risso) [Gurney, 1903; Lebour, I93 I b]. Previous records show larvae in the plankton from March to August. The present records show them in the inshore plankton from May to September, but never in numbers.

Philocheras trispinosus (Risso) [Gurney, 1903; Lebour, I93 $b$ ]. This is an outside species, the larvae occurring in spring and summer. There is only one record from the inshore plankton, in July.

Philocheras bispinosus (Hailstone \& Westwood) [Sars, I890, as P. nanus; Lebour, I93I $b$ ]. Previous records show larvae from June to September. The 
present records show them in the inshore plankton from March to October, but never in numbers.

Hippolyte varians Leach [Sars, 1912; Lebour, 1931 $b$ ]. Larvae were present in the inshore plankton throughout the year, the largest numbers in September and October.

Spirontocaris spp., including $S$. cranchii (Leach) and S. occulta Lebour [Lebour, I936a]. The two species have not been distinguished. They occur in the inshore plankton from January to November, chiefly in spring, summer and early autumn, most common in August to October.

Caridion steveni Lebour [Lebour, I930b]. Previous records show larvae in the plankton from early spring to the middle of August. The present records from inshore plankton show they occur from April to June and in October, but never in numbers.

Pandalus montagui Leach [Webb, 1921; Sars, 1900; Lebour, 1940]. The larvae occur commonly in the outside waters, in spring and summer, and a few in autumn. The present records show them in the inshore plankton from February to October, usually singly.

Pandalina brevirostris (Rathke) [Webb, I92I; Sars, I900; Lebour, I940]. Previous records show the larvae to be very common in the plankton in spring and summer. The present records from inshore plankton show that they occur from January to October, the largest numbers in July.

Processa edulis (Risso) and P. canaliculata Leach [Lebour, 1936b]. Larvae of $P$. canaliculata, almost certainly mixed with $P$. edulis, were formerly recorded in large numbers from the outside plankton from April to September. The present records from inshore waters agree in the seasonal distribution as formerly known, extending for $P$. edulis to October. Apparently $P$. edulis is more numerous in the inshore plankton than $P$. canaliculata.

Leander serratus (Pennant) [Lebour, 1944b]. Gurney (1923) states that all the Leander larvae in the plankton from December to nearly the end of June may confidently be assigned to this species. The present records from inshore waters show that the larvae occur from January to October, with the largest numbers in June, July and August.

Leander squilla (L.) [Gurney, I924]. There are no certain previous records for early larvae of this species from Plymouth. The present records, however, show that they occur in the inshore plankton from May to September, but never in large numbers. The two records in May show that they may breed a little earlier than Gurney suggested.

Nyctiphanes couchii (Bell) [Lebour, 1924, 1925]. Previous records of the larvae are from outside the Breakwater only. The present records show nauplii in small numbers in May and June, and calyptopis and early furcilia in January, March to June, and September to November. Though the numbers are small, these records distinctly indicate that breeding occurs occasionally close inshore. 


\section{REFERENCES TO DECAPOD LARVAE}

Bouvier, E. L.; I9r4a. Recherches sur le Développement post-embryonnaire de la Langouste commune (Palinurus vulgaris). fourn. Mar. Biol. Assoc., Vol. x, pp. I79-93.

- r9r4b. Observations nouvelles sur les trachelifer, larves lucifériformes de Faxea nocturna. Fourn. Mar. Biol. Assoc., Vol. x, pp. I94-206.

Gurney, R., I902. The metamorphosis of Corystes cassivelaunus (Pennant). Quart. Fourn. Micr. Sci., Vol. XLVI, pp. 46I-78.

- I903. The metamorphoses of the Decapod Crustaceans Aegeon (Crangon) fasciatus Risso and Aegeon (Crangon) trispinosus (Hailstone.) Proc. Zool. Soc. London, I903, Vol. II, pp. 24-30.

- - 1923. Some notes on Leander longirostris M. Edwards, and other British prawns. Proc. Zool. Soc. London, 1923, pp. 97-123.

- I924. The larval development of some British prawns (Palaemonidae). II. Leander longirostris and Leander squilla. Proc. Zool. Soc. London, I924, pp. 96I-82.

Lebour, M. V., I924. The Euphausiidae in the neighbourhood of Plymouth and their importance as herring food. Fourn. Mar. Biol. Assoc., Vol. xIII, pp. 402-3I.

- - I925. The Euphausiidae in the neighbourhood of Plymouth. II. Nyctiphanes couchii and Meganyctiphanes norvegica. Fourn. Mar. Biol. Assoc., Vol. xirl, pp. 810-47.

- 1927 . Studies of the Plymouth Brachyura. I. The rearing of crabs in captivity, with a description of the Larval stages of Inachus dorsettensis, Macropodia longirostris and Maia squinado. Fourn. Mar. Biol. Assoc., Vol. xiv, pp. 795-82I.

- I 1928. The larval stages of the Plymouth Brachyura. Proc. Zool. Soc. London, I928, pp. 473-560.

- I $930 a$. The larvae of the Plymouth Galatheidae. I. Munida banffica, Galathea strigosa and Galathea dispersa. Fourn. Mar. Biol. Assoc., Vol. xvII, pp. I75-87.

- I930b. The larval stages of Caridion, with a description of a new species, C. steveni. Proc. Zool. Soc. London, I930, Part I, pp. I8I-94.

- I931 $a$. The larvae of the Plymouth Galatheidae. II. Galathea squamifera and Galathea intermedia. Fourn. Mar. Biol. Assoc., Vol. xvr, pp. 385-90.

- I I93I $b$. The larvae of the Plymouth Caridea. I. The larvae of the Crangonidae. II. The larvae of the Hippolytidae. Proc. Zool. Soc. London, I93I, pp. I-9.

- I932. The larval stages of the Plymouth Caridea. IV. The Alpheidae. Proc. Zool. Soc. London, I932, pp. 463-9.

- I936a. Notes on the Plymouth species of Spirontocaris (Crustacea). Proc. Zool. Soc. London, 1936, pp. 89-104.

- 1936b. Notes on the Plymouth Processa (Crustacea). Proc. Zool. Soc. London, 1936, pp. 609-I7.

- I940. The larvae of the Pandalidae. Fourn. Mar. Biol. Assoc., Vol. xxiv, pp. 239-52.

- I943. The larvae of the genus Porcellana (Crustacea Decapoda) and related forms. Fourn. Mar. Biol. Assoc., Vol. xxv, pp. 72I-37.

- - I $944 \mathrm{a}$. The larval stages of Portumnus (Crustacea Brachyura) with notes on some other genera. Fourn. Mar. Biol. Assoc., Vol. xxvi, pp. 7-15.

— 1944b. Shrimps and prawns. Sch. Sci. Rev., No. 96, pp. 209-16.

— I945. The lobster and its relatives. Sch. Sci. Rev., No. 99, pp. 208-14.

SARS, G. O., 1875. Om Hummerens postembryonale Udvikling. Christiania Vedenskabs-Selskabs Forhandlingar for 1874, pp. I-27.

1889. Bidrag til Kundskaben om Decapodernes Forvandlinger. II. Arch. Math. Naturv., Vol. xIII, pp. I33-201. 
SARS, G. O., I890. Bidrag til Kundskaben om Decapodernes Forvandlinger. III. Fam. Crangonidae. Arch. Math. Naturv., Vol. xiv, pp. I32-95.

- 1900. Account of the postembryonal development of Pandalus borealis Krøyer with remarks on the development of other Pandali, and descriptions of the adult Pandalus borealis. Rep. Norweg. Fish. Invest., Vol. I, No. 3, pp. I-45.

- 1906. Postembryonal development of Athanas nitescens Leach. Arch. Math. Naturv., Vol. xxviI, No. I0, 29 pp.

- I912. Account of the postembryonal development of Hippolyte varians Leach. Arch. Math. Naturv., Vol. xxxir, No. 7, 25 pp.

WebB, G., I919. The development of the species of Upogebia from Plymouth Sound. fourn. Mar. Biol. Assoc., Vol. xir, pp. 8I-I35.

- I92I. The larvae of the Decapoda Macrura and Anomura of Plymouth. Fourn. Mar. Biol. Assoc., Vol. xII, pp. 385-425.

Williamson, C., I9I I. Report on the larval and later stages of Portunus holsatus Fab.; P. puber L.; P. depurator Leach; Hyas areneus (L.) etc. Fish. Scotland Sci. Inv. I909, Vol. I (I9II), pp. I-20.

\section{MOLLUSC LARVAE}

Only a small proportion of mollusc larvae are recognizable in the plankton, but the number has greatly increased during the last ten years. For the first time record has been kept of the occurrence in the inshore plankton of known species. These are mostly gastropods, the bivalve larvae being so much alike, except in a few striking instances, that it is almost impossible to recognize the individual species. Both bivalve and gastropod larvae occur throughout the year in the inshore waters, but they are rarest in the winter months and, usually, most abundant in spring and summer. A large number of bivalve larvae, however, occur in the autumn. The plankton is frequently characterized by one species, such as, for instance, the larva of Mytilus edulis in spring, or Heteranomia squamula in late summer and autumn. Of the gastropods, Rissoids are usually the commonest, but the species of these have not been identified further, although closer investigations can distinguish several genera and species.

Monthly occurrences are shown in Table III.

\section{GASTROPODA}

Many species are included under unidentified gastropod larvae which occur throughout the year, being most plentiful in the present material from June to September. Winter forms include the species of Patella, chiefly $P$. vulgata, Patina pellucida, Trivia arctica and Littorina neritoides. L. littorea, usually commonest in February and March, occurs throughout the year, Trivia monacha from April to September only, Nassarius incrassatus and N. reticulatus from March or April till October. Apparently none of the Turrids breed before May and are seldom seen in autumn. Limacina retroversa is recorded here from May to November, but is much the commonest in summer. 
Patella spp. (chiefly P. vulgata L.) [Smith, I935; Lebour, I937b]. Patella larvae occur from September to April; none has been seen in the intervening months. There is only one record each for April and September, and much the largest numbers occur from November to February, maxima in December and January. The largest numbers seen were in December 1942.

\section{Table III. Mollusc LaRvae a}

Larvae present

Month ... J. F. M. A. M. J. J. A. S. O. N. D.

Gastropod larvae indet.

Patella vulgata

Patina pellucida

Littorina littorea egg capsules

Littorina littorea larva

Littorina neritoides egg capsules

Rissoid larvae

Tornus subcarinatus

Trivia arctica

Trivia monacha

Lamellaria perspicua

Simnia patula

Natica catena

?Bittium reticulatum

Triphora perversa

Cerithiopsis tubercularis

C. barleei

Odostomia sp.

Balcis sp.

Caecum sp.

Nassarius reticulatus

Nassarius incrassatus

? Haedropleura septangularis

Mangelia nebula

Comarmondia gracilis

Philbertia linearis

Tectibranch larva indet.

Eolid larva

Limacina retroversa

Clione sp.

Doto larva

Chiton egg

Bivalve larvae indet.

Anomia (or relative)

Mytilus (or relative)

Pecten (or relative)

Lima hians

Kellia suborbicularis

?Mysella sp.

Ensis sp. (or relative)

Hiatella arctica

?Teredo sp.

Patina pellucida (L.) [Lebour, 1937b]. The larvae occur in the present records in August, September, November, December and February, but never in large numbers.

Littorina littorea (L.) [Lebour, I937b]. The egg capsules occur very commonly in the inshore plankton, being present all the year. Although 
February and March appear to be the chief breeding season (Moore, I937), and maximum numbers occurred in March, they were sometimes plentiful from January to June, and from August to December. Indeed it is difficult to indicate any distinct breeding season. The larvae were frequently abundant in almost any month.

Littorina neritoides (L.) [Linke, I935; Lebour, 1935b, I937b]. Previous records of the spawning periods (Lysaght, I94I) were from September to April. The present records of the egg capsules are from December to April and in October. It is thus distinctly a winter and early spring breeder. Lysaght connected the main spawning with the high tides at fortnightly intervals.

Rissoid larvae [Lebour, 1934 a, I936, I937b]. These are chiefly Rissoa parva (da Costa). Several other species are included but have not been distinguished. They occur throughout the year, often in large numbers, in the inshore plankton. These are fewest in December and January, most plentiful from April to December.

Tornus subcarinatus (Montagu) [Lebour, I936]. The larvae were previously recorded from the plankton in summer (Lebour, 1936). The present records show them occurring only in November and December and then very rarely.

Trivia arctica (Montagu) [Lebour, I933a, 1935a]. The larvae occur in the present inshore plankton records from January to May only. They have previously been recorded autumn to early spring but never in summer. May is rather exceptionally late.

Trivia monacha (da Costa) [Lebour, I93I $b, \mathrm{I} 933 a$, I935a, I937b]. This is known to be a late spring and summer breeder. The present records show it occurring from April to September. Thus the larva may overlap T. arctica in April and May but never occurs in the winter.

Lamellaria perspicua (L.) [Lebour, I935a] was present throughout the year, but never in large numbers. It occurred most commonly in June and July; and only once in February.

Simnia patula (Pennant) [Lebour, 1932a, 1937b]. This usually occurs in outside waters. It is a summer breeder, recorded here from the inshore waters from June to September, fairly plentiful once in August 1942.

Natica (Lunatia) catena (da Costa) [Lebour, 1936, 19376]. A summer breeder, previously recorded in late spring and summer. The present records show it from March to October in the inshore waters, commonest in June and July.

?Bittium reticulatum (da Costa) [Lebour, 1936]. Larvae which are probably this species have previously been recorded as common in spring and summer. The present records show it in July and August only.

Triphora perversa (L.) [Lebour, $1933 b$ ] is usually present commonly in the outside water although occasionally occurring inside, in spring, summer and autumn. The present records show it from July to October but never in numbers. 
Cerithiopsis tubercularis (Montagu) [Lebour, I933b]. Previously recorded as common in both inshore and outside plankton in spring, summer and autumn but usually outside. The present records show it in inshore waters from June to October, but not in large numbers.

Cerithiopsis barleei Jeffreys [Lebour, 1933b] was previously recorded in spring, summer and autumn. Here it is recorded, in the inshore waters, only in August.

Odostomia sp. (or relative) [Lebour, 1937b] and Balcis sp. [Lebour, 1935c] were each only seen once, in September.

Caecum sp., probably imperforatum (Kunmacher) [Lebour, 1936]. Previous records show that it is common in the summer and autumn plankton. The present records show it present from July to January, largest numbers in November.

Nassarius reticulatus (L.) [Lebour, I93I $a$ ] was previously recorded throughout the year but especially in spring and summer. The present records show it to be present from March to October, largest numbers from March to June.

Nassarius incrassatus (Ström) [Lebour, 193I a]. Larvae have been found in the plankton (usually outside the Breakwater) throughout the year but especially in spring and summer. The present records show them in the inshore plankton from April to October. They are not so common as N. reticulatus in these records, being most abundant from May to August.

?Haedropleura septangularis (Montagu) [Lebour, 1936]. The larvae probably belonging to this species are fairly common in the inshore plankton from May to September but never in numbers, July being the maximum month.

Mangelia nebula (Montagu) [Lebour, 1934b]. Breeding is known to take place in summer and larvae are usually common both in inshore and outside, shallow-water, plankton. The present records show it present, in small numbers only, from July to November.

Philbertia (Comarmondia) gracilis (Montagu) [Lebour, 1933c, 1934b]. The larvae are fairly common in outside waters in spring and summer. The present records show it from May to September, most frequent in July and August.

Philbertia linearis (Montagu) [Lebour, 1934b]. Previous records show it to be fairly common in spring and summer, both inshore and outside. The present records show it from June to October, fairly commonly, most abundant in July.

Tectibranch larva indet. These are present throughout the year, often in numbers, especially in autumn and winter.

Limacina retroversa (Fleming) [Lebour, I932b]. Although this is an oceanic mollusc it is frequently common in the inshore plankton, in the adult, young or larval stage. The present records show it from May to November but never in the other months. In 1940 they were very abundant with the maximum in August and September. In 1942 they only began in July, the maximum being 
in September, when they were very numerous. In 1943 they were only seen in July and August and were never abundant; in 1944 they began in May, were common in July and disappeared after August; and in 1945 they began in July when they were numerous, still more so in August, and disappeared after October. In all the samples the young stages were more numerous than adults, and larvae were frequently present, showing that breeding must have taken place close inshore.

Clione sp. This is a dark brown species, not identified. It occurred in the young stage singly or in very small numbers in February to May in the present inshore samples.

Eolid larva indet. (Pelseneer, I9II). Eolid larvae occur in the inshore plankton throughout the year, especially in summer, and most numerous in June.

Doto sp. larva. This larva with a huge velum and spiral shell occurs from June to September, usually singly, but fairly frequently, in the inshore waters.

Chiton eggs. These occur singly or in small numbers, in the inshore plankton from February to November.

\section{LAMELLIBRANCHIATA}

Bivalve larvae indet. occur throughout the year in the present samples, frequently in large numbers. It has already been shown (Lebour, 1938b) that a large outburst of these larvae usually occurs in late summer or autumn, and this also occurs in the present records from inshore. These are usually few in January, but in I944 and I945 they were fairly common, as well as in February I 943 and I944. The largest numbers however nearly always occur in September. In early spring the larva of Mytilus edulis nearly always predominates.

Anomia (or relative) [Lebour, I938 b]. The larvae of this group occur almost throughout the year in the present samples, only March and April excepted. They usually form a large part of the late summer or early autumn outburst and they are probably Heteranomia squamula (L.). This species may breed throughout the year although the height is in late summer and early autumn. In the present records it was specially numerous from August to October.

Mytilus (or relative). M. edulis breeds, as is stated above, chiefly in spring. Nearly all the records in spring and early summer probably refer to this species, but its relatives are so like it in the larval stages that it is not possible to be sure of this. The largest numbers occur in May, but except in March, September and December, they are recorded in every month.

Pecten (or relative). These occur throughout the year in the present records but the species are unrecognizable and they are seldom abundant. Largest numbers were in September and October.

Lima hians Gm. [Lebour, I937a]. This remarkable larva has already been shown to occur most frequently in the plankton in late summer and early 
autumn. It is found in both inside and outside plankton. The present inshore records show it present in January, and March, and from June to December, but it is much more abundant from September to November, the largest numbers occurring in October and November.

A different species of Lima larva, almost certainly L. loscombi Sowerby (Fig. I), which is the only other species in the district, was seen once in September 1942, shell $0.40 \mathrm{~mm}$. across. It is interesting because the velum is very large, much larger than in L. hians, and is indented in the centre of each lobe, thus approximating to a four-lobed velum-a very rare feature in the Lamellibranchs.

Kellia suborbicularis (Montagu) [Lebour, I938a] breeds throughout the year, and the larvae are common in the plankton, but especially in summer and autumn. Most numerous in August and September, this larva is one of the largest and most conspicuous of the Lamellibranchs.

Mysella sp. larva [Lebour, 1938b]. These occurred in the inshore plankton in February and from August to October, but not in such large numbers as they were found in outside waters in previous records. They were most numerous in September.

Ensis sp. or relative [Lebour, $1938 b$ ]. It is difficult to distinguish the species in

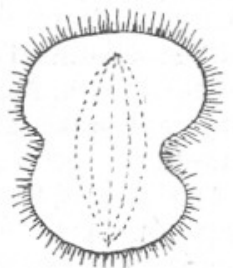

$a$

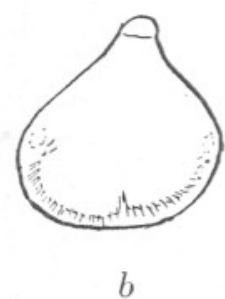

Fig. I. Veliger of Lima sp., probably Lima loscombi. Shell 0.40 mm. across. $a$, Veliger swimming $b$, lateral view of shell.

the young stages, although Cultellum pellucidus can usually be recognized after the smallest stages by the red pigment behind the siphon. As a rule the larva of Ensis siliqua (L.) is common in the early spring months, characterizing the plankton, Cultellus pellucidus breeding later, usually in autumn and winter. Collectively the larvae of all the relatives of Ensis occur in the present inshore plankton throughout the year, except December, largest numbers in November I94I and January 1942 (probably Cultellus pellucidus) and in March I945 (probably Ensis siliqua).

Hiatella arctica (L.) [Lebour, I938b] was present in the inshore plankton in every month except December and January, especially abundant in late summer and autumn, the largest numbers in September and October.

Teredo larva [Lebour, 1938b]. These were rarely found in the present samples. Larvae, almost certainly Teredo navalis var., occurred singly in August and October. It was found (Lebour, I946) that this species carried active larvae throughout the year. 


\section{REFERENCES TO MOLLUSC LARVAE}

Lebour, M. V., I93I $a$. The larval stages of Nassarius reticulatus and Nassarius incrassatus. Fourn. Mar. Biol. Assoc., Vol. xvII, pp. 797-8I7.

I93I $b$. The larval stages of Trivia europea. Fourn. Mar. Biol. Assoc., Vol. xvir, pp. 8I9-3I.

- I932a. The larval stages of Simnia patula. Fourn. Mar. Biol. Assoc., Vol. xvIII, pp. 107-I5.

— I932 b. Limacina retroversa in Plymouth waters. Fourn. Mar. Biol. Assoc., Vol. XviII, pp. I23-9.

- I933a. The British species of Trivia: T. arctica and T. monacha. Fourn. Mar. Biol. Assoc., Vol. xviII, pp. 477-84.

- I933b. The life-histories of Cerithiopsis tubercularis (Montagu), C. barleei Jeffreys and Triphora perversa (L.). Fourn. Mar. Biol. Assoc., Vol. xvirI, pp. $49 \mathrm{I}-8$.

- I933c. The eggs and larvae of Philbertia gracilis (Montagu). Fourn. Mar. Biol. Assoc., Vol. xvIII, pp. 507-IO.

- I $934 a$. Rissoid larvae as food of the young herring. The eggs and larvae of the Plymouth Rissoidae. Fourn. Mar. Biol. Assoc., Vol. xIx, pp. 523-39.

- I $1934 b$. The eggs and larvae of some British Turridae. Fourn. Mar. Biol. Assoc., Vol. XIX, pp. 54I-54.

- I I935a. The Echinospira larvae (Mollusca) of Plymouth. Proc. Zool. Soc. London, 1935, pp. 163-74.

- $1935 b$. The breeding of Littorina neritoides. Fourn. Mar. Biol. Assoc., Vol. xx, pp. $373-8$.

I935c. The larval stages of Balcis alba and B. devians. Fourn. Mar. Biol. Assoc., Vol. xx, pp. 65-9.

- 1936. Notes on the eggs and larvae of some Plymouth Prosobranchs. Fourn. Mar. Biol. Assoc., Vol. xx, pp. 547-65.

- I937a. Larval and post-larval Lima from Plymouth. Fourn. Mar. Biol. Assoc., Vol. xxi, pp. 705-Io.

- 1937b. The eggs and larvae of the British Prosobranchs with special reference to those living in the plankton. Fourn. Mar. Biol. Assoc., Vol. xxII, pp. 105-66.

I 1938 a. The life history of Kellia suborbicularis. Fourn. Mar. Biol. Assoc., Vol. xxII, pp. 447-5I.

- I $938 b$. Notes on the breeding of some Lamellibranchs from Plymouth and their larvae. Fourn. Mar. Biol. Assoc., Vol. xxiII, pp. II9-44.

— I946. The species of Teredo from Plymouth waters. Fourn. Mar. Biol. Assoc., Vol. Xxvi, pp. 38I-9.

Linke, O., I935. Der Laich von Littorina (Melaraphe) neritoides L. Zool. Anz., Bd. II2, Heft 3-4, pp. 57-62.

Lysaght, A. M., I94I. The biology and trematode parasites of the Gastropod Littorina neritoides (L.) on the Plymouth Breakwater. Fourn. Mar. Biol. Assoc., Vol. xxv, pp. $4 \mathrm{I}-67$.

Moore, H. B., I937. The Biology of Littorina littorea. Part I. Growth of the shell and tissues, spawning, length of life, and mortality. Fourn. Mar. Biol. Assoc., Vol. xxI, pp. 72I-42.

Pelseneer, P., I9il. Recherches sur l'embryologie des Gastropodes. Mem. Acad. $R$. de Belg., 2e. Ser., T. III, I67 pp.

Smith, F. G. W., I935. The development of Patella vulgata. Phil. Trans. R. Soc. London, ser. B, No. 520, Vol. 225, pp. 95-I25. 


\section{ANNELID LARVAE}

Monthly occurrences are shown in Table IV.

TABLE IV. ANNELID LARVAE

Larvae present

Polygordius lacteus

P. appendiculatus

Polynoid larva

Tomopteris helgolandicus (juv.)

Syllid larva

Autolytus sp. $\sigma^{\circ}$

Autolytus sp. 우 with eggs

Nereid larvae

Nereid eggs

Spionid larvae and eggs

Nerine larva

Magelona papillicornis

Magelona sp. (? cincta)

Magelona sp.

Poecilochaetus serpens

Chaetopterus larva

Arenicola larva

Owenia larva

Pectinaria sp. (?koreni)

Lanice conchilega

Loimia medusa

Annelid larva indet.

Month ... J. F. M. A. M. J. J. A. S. O. N. D. 
Tomopteris helgolandicus Greef [Apstein, 1900]. Young of this worm, not larvae, occurred in the inshore plankton rarely. It usually is to be found outside. Single specimens were seen from July to November.

Syllid larvae indet. [Johnstone, Scott \& Chadwick, I924] were recognized in the inshore plankton in June and July; but not abundant.

Autolytus sp. (adult ${ }^{7}$ ) [Johnstone, Scott \& Chadwick, 1924] occurred in every month except February but usually singly.

Autolytus (o with eggs) occurred in every month except December, usually in summer, nearly always singly. Sometimes the larvae were hatching from the eggs.

Nereid eggs and larvae indet. [Wilson, 1932a]. These occurred in the inshore plankton in any month except June and August, the largest numbers in September and November.

Spionid larvae and eggs indet. [Wilson, I928b] occurred in the inshore plankton from October to April and June to August the largest numbers in March and April.

Nerine larva? was found rarely in the inshore plankton in February and March.

Magelona papillicornis Fr. Müller [Johnstone, Scott \& Chadwick, I924]. This is one of the commonest larvae of the inshore plankton, recorded in every month except February. It is much the commonest in late spring and summer, particularly May to July, and was once abundant in October.

Magelona, ?cincta (Ehlers) was not so plentiful as M. papillicornis, but occurred in the inshore plankton from April to October, abundant in May, July and August.

Magelona sp. This third species, unidentified as yet, occurs in the inshore plankton from May to October, but is never numerous.

Poecilochaetus serpens Allen [Allen, 1904] occurs in the inshore plankton from February to November, previous records being only in the summer months ('not uncommon' according to Allen). It is more numerous, however, in spring and summer. The largest numbers seen were in May.

Chaetopterus larva indet. [Johnstone, Scott \& Chadwick, I924] was found from August to November in the inshore plankton, never in large numbers.

Arenicola larva indet. [Ashworth, I9I2] was occasionally seen in the inshore plankton from March to May and in November. It was never numerous.

Owenia larva [Wilson, 1932b] was found once only in the inshore plankton, in July.

Pectinaria larva (?koreni) [Gravely, I909; Wilson, 1936] occurred in the inshore plankton from April to August and in December, never in large numbers, but was fairly frequent in July 1942 .

Lanice conchilega (Pallas) [Johnstone, Scott \& Chadwick, 1924], one of the commonest annelid larvae in the inshore plankton, occurred in every month except January; commonest from April to October, rare in the other months. 
Loimia medusa (Savigny) [Wilson, I928a] was common in the inshore plankton from January to June, most frequent from March to May.

Annelid larvae indet. were in the inshore plankton in every month chiefly in spring and summer.

\section{REFERENCES TO ANNELID LARVAE}

Allen, E. J., I904. The anatomy of Poecilochaetus, Claparède. Q. Fourn. Micr. Sci., Vol. xuviII, pp. 79-I5I.

Apstein, C., I900. Die Alciopiden und Tomopteriden der Plankton Expedition. Plankton Exped., Bd. 2, pp. I-6r. Kiel.

Ashworth, J. H., I912. Catalogue of the Chaetopoda in the British Museum (Natural History). A. Polychaeta. Part I. Arenicolidae. Pp. I-I75.

Gravely, F. H., I909. Polychaet Larvae. Liverpool M.B.C. Memoirs, Vol. xix, $79 \mathrm{pp}$.

Johnstone, Scott \& CHADWICK, 1924. The Marine Plankton. Liverpool University Press. I94 pp.

OKaDA, Yô K., I930. A remark on the constitution of larval Syllids. Fourn. Mar. Biol. Assoc., Vol. xvi, pp. 479-87.

WILson, D. P., I928a. The post-larval development of Loimia medusa Sav. Fourn. Mar. Biol. Assoc., Vol. xv, pp. I29-49.

- I $928 \mathrm{~b}$. The larvae of Polydora ciliata Johnston and Polydora hoplura Claparède. Fourn. Mar. Biol. Assoc., Vol. xv, pp. 567-603.

1929. The larvae of the British Sabellarians. Fourn. Mar. Biol. Assoc., Vol. xvi, pp. $22 \mathrm{I}-69$.

- I 932 a. The development of Nereis pelagica Linnaeus. Fourn. Mar. Biol. Assoc., Vol. xviII, pp. 203-I7.

- I932b. On the Mitraria larva of Owenia fusiformis Della Chiaje. Phil. Trans. R. Soc. London, Ser. B, Vol. 221, pp. 23I-334.

I936. Notes on the early stages of two Polychaetes, Nepthys hombergi Lamarck and Pectinaria Koreni Malingren. Fourn. Mar. Biol. Assoc., Vol. xxI, pp. 305-10.

WoltereCK, R., I902. Trochophora-Studien. I. Ueber die Histologie der Larve und die Entstehung des Annelids bei den Polygordius-Arten der Nordsee. Zoologica, Bd. xIII, Heft 34, pp. I-7I.

- I925. Neue und alte Beobachtungen zur Metamorphose der Endolarve von Polygordius (mit einem Zusatz, der die letzten Mitteilungen Dr Söderströms betrifft). Zool. Anz., Bd. Lxv, Heft I-2, pp. 49-60.

\section{Other Plankton LaRvae}

Monthly occurrences of larvae from miscellaneous groups are shown in Table V.

\section{Turbellaria}

Müller's larva, probably Cycloporus papillosus Lang [Lang, I884]. This larva has not been identified, but it is very likely to be the same species which Orton recorded in the Plymouth Fauna List as probably this species, having hatched it from the egg (I9 August I9I2). It occurs fairly frequently from July to October in the inshore plankton, but has not been seen in other months. 


\section{Table V. Miscellaneous Larvae}

Larvae present

Müller's larva

Month ... J. F. M. A. M. J. J. A. S. O. N. D.

Pilidium

Cyphonautes

Tornaria

Actinotrocha

Echinopluteus (unidentified)

Ophiopluteus (Ophiothrix)

Ophiopluteus (ophiuroid)

Bipinnaria of Asterias

Auricularia (unidentified)

Luidia larva

\section{Nemertinea}

Pilidium larva, unidentified, probably belonging to Lineus sp. [Macbride, I9I4] or Cerebratulus sp. [Sedgwick, I898]. Two or three different species occurred in the inshore plankton from March to November (excepting July) but nearly always singly, never in numbers.

\section{Bryozoa}

Cyphonautes larva unidentified [Johnstone, Scott \& Chadwick, 1924] probably Membranipora sp. Two different species, and occasionally a third, occur very commonly in the inshore plankton in any month. Largest numbers occurred in May 1943, but they may be abundant in any month.

\section{Enteropneusta}

Tornaria larva of Balanoglossus [Bourne, I889], previously recorded as abundant in the Sound in summer. The present inshore records show it occurring only occasionally in small numbers or singly from June to August.

\section{Phoronidea}

Actinotrocha larva of Phoronis [Johnstone, Scott \& Chadwick, I924, erroneously designated Balanoglossus] occurs in the inshore plankton (probably two species) from April to August and in December, most frequent from May to July.

\section{Echinodermata}

By far the commonest larvae of the Echinoderms in the inshore plankton is the Ophiopluteus of Ophiothrix fragilis; next come Echinoplutei unidentified. Others occur much less frequently.

Ophiopluteus of Ophiothrix fragilis (Abildgaard) [Johnstone, Scott \& Chadwick, 1924] occurs from February to November but most commonly from June to September, sometimes in large numbers.

Ophiopluteus of ophiuroid unidentified [Mortensen, I927] occurs occasionally in the inshore plankton from July to October, never in large numbers, commonest in August. 
Echinopluteus unidentified [Mortensen, 1927], probably chiefly Echinocardium and Echinocyamus, occurs in the inshore plankton from May to November, chiefly in summer, commonest July and August.

Auricularia larva of Holothurian unidentified [Mortensen, 1927] occurs rarely in the inshore plankton from March to July, never in numbers.

Bipinnaria larva of Asterias [Mortensen, I927] occurs very rarely in the inshore plankton in June and July.

Bipinnaria larva of Luidia [Mortensen, 1927] occurred only once in July I944. It is usually entirely confined to the outside waters.

\section{OTHER REFERENCES}

Bourne, G. C., I889. On a Tornaria found in British Seas. Fourn. Mar. Biol. Assoc., Vol. I, pp. 63-8.

Cunningham, J. T., I892. On a species of Siphonophore observed at Plymouth. Fourn. Mar. Biol. Assoc., Vol. II, pp. 212-I5.

Johnstone, Scott \& Chadwick, I924. The Marine Plankton. Liverpool University Press. I94 pp.

LANG, A., I884. Die Polycladen (Seeplanarien) des Golfes von Neapel und der angrenzenden Meeresabschnitte. Fauna und Flora des Golfes von Neapel, Bd. XI, pp. I-688.

Lebour, M. V., I947. An interesting young Velella in the Plymouth plankton. Fourn. Mar. Biol. Assoc., Vol. xxvi, pp. 548-50.

MACBride, E. W., I9I4. Text Book of Embryology. Vol. I. Invertebrata. London.

Mortensen, T., I927. Handbook of the Echinoderms of the British Isles. 47I pp.

RUSSELl, F. S., I934. On the occurrence of the Siphonophores Muggiaea atlantica Cunningham and Muggiaea kochi (Will) in the English Channel. Fourn. Mar. Biol. Assoc., Vol. xIx, pp. 555-8.

- 1938. On the development of Muggiaea atlantica Cunningham. Fourn. Mar. Biol. Assoc., Vol. xxir, pp. 44I-6.

Sedgwick, A., I898. A Student's Text-Book of Zoology. Vol. I. Protozoa to Chaetognatha. London. 